Arabiyat : Jurnal Pendidikan Bahasa Arab dan Kebahasaaraban

\title{
ARABIC LEARNING AT MADRASAH ALIYAH BASED ON THE 2013 CURRICULUM
}

\author{
Iis Susiawati, Moch. Hasyim Fanirin \\ Indonesian Islamic Institute of Az-Zaytun (AL-AZIS) Indramayu, Indonesia \\ Mekarjaya, Alzaytun, Kabupaten Indramayu, Jawa Barat, 45264, Indonesia \\ Corresponding E-mail:umifaiz@gmail.com
}

\begin{abstract}
The purpose of this study was to obtain information and data about the implementation of the 2013 curriculum from the aspects of planning, implementation and evaluation as well as the factors that influence the process of implementing the 2013 curriculum at Madrasah Aliyah Nurul Hikmah Haurgeulis Indramayu. The study was conducted in Madrasah Aliyah Nurul Hikmah Haurgeulis as a representation of madrasas that have implemented the 2013 Curriculum in learning Arabic. This research was a field research with a qualitative approach. Data obtained from three sources, namely observation, interviews and documentation. The subjects of this study were the principal, the curriculum section and the tenth grade students of Madrasah Aliyah Nurul Hikmah Haurgeulis Indramayu. The results of this study indicate that the implementation of the 2013 Curriculum at Madrasah Aliyah Nurul Hikmah Haurgeulis Indramayu, especially in learning Arabic, was still not running optimally according to the parameter criteria. There were several factors that influence the implementation process of the 2013 Curriculum, namely teachers, students and infrastructure.
\end{abstract}

Keywords: the 2013 curriculum, Arabic learning, Madrasah Aliyah

\section{Introduction}

The 2013 curriculum is formulated using methods that suit the needs of students, with real learning and students playing an active role. It is expected to produce a thought process that continues to develop well. The 2013 curriculum shows that a certain subject can be integrateed to other subject. ${ }^{1}$

The 2013 curriculum in its preparation is based on the following aspects ${ }^{2}$. The first is philosophical aspect. The 2013 Curriculum in this context is education based

\footnotetext{
${ }^{1}$ Mushoffan Prasetianto, "CLIL: Suggested English Materials for Curriculum 2013”, Language Circle, Journal of Language and Literature, Vol. 8, No. 2, 2014.

2 M. Fadlilah, Implementasi Kurikulum 2013 dalam Pembelajaran SD/MI, SMP/MTs dan SMA/MA, (Yogyakarta: Ar-Ruzz Media, 2014), 29-30.
} 
on noble values, academic values, the needs of students and society. The curriculum is oriented towards competency development. The second, juridical aspects that is a foundation used as a legal umbrella in the preparation and development of the curriculum. One of the juridical foundations is Permendikbud Number 81A of 2013 concerning Implementation of the 2013 Curriculum. The third, conceptual aspect, a foundation based on ideas or ideas that are abstracted from concrete events.

Curriculum and learning are two important aspects of educational activities. Both discussed what education is and how it should be implemented. ${ }^{3}$ Therefore the important role of the curriculum in the educational process should be anticipatory and adaptive to changes and developments and advances in science and technology. Both require understanding and study in their application and implementation in schools. Therefore, the curriculum is an important factor in the learning process. Because the curriculum is a set of various subjects that must be studied by students. ${ }^{4}$ The curriculum must keep abreast of developments in science and technology, so that it can be better applied in the learning process.

The 2013 Curriculum is basically a refinement of the previous curriculum. The target of curriculum change is the teacher as the direct implementers in the classroom. While curriculum is the planned program, teachers are the actors that implement the program through teaching and learning process. This is the relationship between curriculum, teachers, and learning. ${ }^{5}$

The target of the 2013 Curriculum is to increase and balance between attitudes, skills, and knowledge competencies. In accordance with Law no. 20 of 2013 as stated in the explanation of Article 35: graduate competence is a qualification of graduate abilities that includes attitudes, knowledge and skills according to agreed national standards. This is also in line with the development of the Competency-Based Curriculum (CBC) which was initiated in 2004 which includes competency in attitudes, knowledge and skills in an integrated manner. Where as in language learning, especially Arabic has its own approach which is an implementation of linguistic theory and learning psychology, especially for novice learners.

The 2013 Curriculum policy is aimed at improving the previous curriculum. Entering the new academic year 2014/2015 until now, the implementation of the 2013 Curriculum still faces major obstacles. Basically, the application of the curriculum in learning is not only seen from the curriculum design, but more importantly, in reality. In addition, there are also several factors that can affect the process of learning activities including teacher, student, facilities, tools and available media. ${ }^{6}$ Meanwhile, according to Mars in Sulfemi, there are three influential factors in the implementation

3 Azkia Muharom Albantani, "Implementasi Kurikulum 2013 pada Pembelajaran Bahasa Arab di Madrasah Ibtidaiyah", Arabiyat : Jurnal Pendidikan Bahasa Arab dan Kebahasaaraban, Vol. 2 No. 2, 2015.

4 Ahmad Janan Asifudin, Mengukir Pilar-Pilar Pendidikan Islam, (Tinjauan Filosofis), (Yogyakarta: Suka Press, 2010), 111.

${ }^{5}$ Maulidia Rachmawati Nur and Ahmad Madkur, "Teachers Voices on the 2013 Curriculum for English Instructional Activities", IJEE, Vol. 1, No. 2, 2014.

6 Wina Sanjaya, Kurikulum dan Pembelajaran, (Jakarta: Kencana Prenada Media Group, 2009), 197. 
Arabiyât Jurnal Pendidikan Bahasa Arab dan Kebahasaaraban, 7 (2), 2020

of the curriculum, namely the support of the principal, support of peer teachers and internal support in the classroom.

The 2013 curriculum is a new curriculum which began its implementation in 2013/2014. While the implementation of the 2013 Curriculum in madrasas is in accordance with the Circular of the Director General of Education of the Ministry of Religion of the Republic of Indonesia No. SE / Dj.I / PP.00 / 50/2013 (Dirjen Pendis Kemenag RI, 2013) which was signed by the Director General of Islamic Education on July 8, 2013 by considering personnel preparation and budget readiness at the Ministry of Religion only started in 2014/2015 lesson year specifically for class I, IV, VII and X only. ${ }^{8}$ This curriculum is a development of the existing curriculum, namely the Competency-Based Curriculum (KBK) which was initiated in 2004 and the Education Unit Level Curriculum (KTSP) in 2006. It's just that the emphasis in the 2013 curriculum is the improvement and balance of soft and hard skills. skills which include aspects of competence attitudes, knowledge and skills.

As stated by Putra and Gunawan (in Gunawan), the 2013 Curriculum emphasizes greatly in building student's characters, developing relevant skills based on student interests and needs and developing a thematic approach that benefits student's cognitive abilities. ${ }^{9}$

The scientific approach as a modern pedagogic dimension in learning is also emphasized in this 2013 Curriculum. The scientific approach includes: observing, asking, reasoning, trying, and forming networks. The learning process in the 2013 curriculum touches three domains, namely attitudes, skills and knowledge. As for the assessment process using authentic assessment, which is a significant measurement of the learning outcomes of students in the three assessed domains. Saddhono in Dewi stated that this scientific approach is a learning process that support creativity. ${ }^{10}$ The 2013 curriculum entry emphasizes the activities based learning. Therefore, the assessment will have more emphasis on the process in the aspect of attitudes, knowledge, and skill. ${ }^{11}$

7 Wahyu Bagja Sulfemi, Manajemen Kurikulum di Sekolab: Modul Pembelajaran Program Studi Administrasi Pendidikan STKIP Muhammadiyah Bogor, (Bogor: Visi Nusantara Maju, 2018), 32.

8 Andi Prastowo, "Transformasi Kurikulum Pendidikan Dasar dan Menengah di Indonesia (Kurikulum Tingkat Satuan Pendidikan Menuju Kurikulum 2013 hingga Kurikulum Ganda)", JIP: Jurnal Ilmiah PGMI, Vol. 4, No. 2, 2018.

9 Imam Gunawan, "Indonesian Curriculum 2013: Instructional Management, Obstades Faced by Teachers in Implementation and the Way Forward", ICET, Atlantis Press, Advences in Social Science, Education and Humanities Research, Vol. 128

10 Dewi Kusumaningsih, "Indonesian Text Role as Draft Science in Curriculum 2013: Assessment Introduction Text Structure Strategies in an Indonesian Book", Asian Journal of Social Sciences \& Humanities, Vol. 2, No. 4, 2013.

11 Fauzan and Anis Fuadah Zuhri, "Analysing The Essence of Fiqh Subjects in Curriculum 2013", Abkam, Vol. 17, No. 1, 2017. 
The purposes of the 2013 Curriculum $^{12}$ are to improve the quality of education by balancing soft skills and hard skills through the ability of attitudes, skills and knowledge in order to face growing global challenges; to form and increase productive, creative and innovative human resources as capital for the development of the nation and state of Indonesia; to relieve educators in delivering material and preparing teaching administration, where the government has prepared all curriculum components along with textbooks used in learning; to increase the participation of central and local governments as well as community members in a balanced manner in determining and controlling quality in the implementation of the curriculum at the educational unit level; and to increase healthy competition between education units regarding the quality of education to be achieved. Schools are given the flexibility to develop the 2013 Curriculum according to the conditions of the education unit, the needs of students and regional potential.

Implementation in realizing curriculum purposes needs organizing learning, choosing the right learning approach, determining learning procedures, establishing competencies effectively, establishing success criteria, and educating who is required to be able to design effective and fun (meaningful) learning.

Problems in learning Arabic can be seen from two aspects: 1) linguistic problems which include speech, qawa'id nabwiyyah sharfiyyah, ta'addud al-ma'na, mutaradifat, and others. According to Fachrurrozi and Mahyudin (in Hasyim), this problem of learning Arabic must be fixed because a person's understanding of the components of language determines how he teaches a language. 2) non-linguistic problems include approaches, methods, media, teaching materials, motivation in learning, time allocated for learning and learning objectives. ${ }^{13}$

Arabic is the language used by Arabs and their peninsula as a means of communication between them in expressing certain goals so that they are able to interact based on geographic location, culture and civilization. ${ }^{14}$ According to A. Fuad Effendy, Arabic is the Koran, the language of communication between Muslims, whose role is not only as a means of communication between humans and others, but also as a means of communication for humans who believe in Allah, which is manifested in the form of ritual and worship. ${ }^{15}$ According to al-Ghulayain, Arabic are sentences used by Arabs to express their goals (thoughts and feelings). And these goals have reached us how to translate it, and al-Quran al-Karim and al-Hadith AsSharif protect it for us, and something in the form of prose and poetry that has been

12 M. Fadlilah, Implementasi Kurikulum 2013 dalam Pembelajaran SD/MI, SMP/MTs dan SMA/MA, 24.

${ }^{13}$ M. Hasyim, "Andragogi dalam Pembelajaran Bahasa Arab", Arabiyat : Jurnal Pendidikan Bahasa Arab dan Kebahasaaraban, Vol. 2, No. 1, 2015.

14 Zulhanan, Paradigma Baru Pembelajaran Bahasa Arab (Kajian Teoritis dan Praktis), (Bandar Lampung: An-Nur Press, 2004), 1.

15 A. Fuad Effendy, Metodologi dan Strategi Alternatif (Pembelajaran Bahasa Arab), (Malang: Misykat, 2005), 17-18. 
Ara biyât Jurnal Pendidikan Bahasa Arab dan Kebahasaaraban, 7 (2), 2020

narrated by experts. ${ }^{16}$ Meanwhile, according to Taufiq, Arabic is the language used by communities in the Arabian Island. ${ }^{17}$

The purpose of learning Arabic is to master the knowledge of language and Arabic language proficiency, such as muthala'ah, mubadatsah, insya', nabwu and sharf. Learning Arabic is an ideal discipline, which includes ideology (religion), science, and social life.

Madrasah Aliyah (MA) Nurul Hikmah Haurgeulis Indramayu is one of the private madrassas that has implemented the 2013 Curriculum. According to the results of interviews with the Head of Madrasah, so far no one has researched the application of the 2013 curriculum in madrasas to Arabic language subjects, while there have been other subjects, namely biology. Therefore the authors are interested in raising the problem of implementing the 2013 Curriculum in learning Arabic for class X Madrasah Aliyah Nurul Hikmah Haurgeulis Indramayu and want to find out whether the implementation of the 2013 Curriculum in madrasah has gone well in planning, implementation and evaluation as well as the factors that influence the process.

\section{Method}

This research was qualitative in nature, which is a research approach that produces descriptive data in the form of written or oral data from people and observable behavior. ${ }^{18}$ According to the type, this research is field research, namely research that aims to conduct an in-depth study of a social unit in such a way as to produce a well-organized and complete picture of the social unit. ${ }^{19}$ The form of this research is descriptive research (descriptive research), which is research that describes an object with regard to the problem under study without questioning the relationship between research variables. ${ }^{20}$

In this research, the authors used case research which aims to study intensively about the background of a person, group or institution, in detail and in depth about a particular organization, institution or phenomenon. ${ }^{21}$ Virgiana states that the subject of research is an object, thing or person attached to data about the object of research. ${ }^{22}$ Sources of data in this study are the subjects from which data can be obtained and collected, namely literary data sources, data sources obtained from books written by experts in accordance with the problem under study, including scientific papers, papers and publications related to the curriculum. 2013. Includes documents

\footnotetext{
16 Musthafa al-Ghulayain, Jami' ad-Durus al-'Arabiyah, (Al-Iskandariyah: Dar Al-'Aqidah, 2014), 5.

17 WildanTaufiq, Metode Penelitian Bahasa Arab, (Bandung: PT Refika Aditama, 2018), 11-12.

${ }^{18}$ Lexy J. Moleong. Metodologi Penelitian Kualitatif. Bandung: Remaja Rosdakarya, 2002, h. 3

19 Dudung Abdurrahman, Pengantar Metode Penelitian, (Yogyakarta; Kurnia Kalam Semesta, 2003),

${ }^{20}$ Sanapiah Faisol, Format-Format Penelitian Sosial, (Jakarta: Raja Grafindo Persada, 2007), 18.

21 Suharsimi Arikunto, Prosedur Penelitian Suatu Pendekatan Praktek, (Jakarta: Rineka Cipta, 2002),

22 Angga Virgiana, Strategi Pengembangan Kompetensi Widyaiswara dalam Pengelolaan Pembelajaran di Lembaga Pusat Pengembangan dan Pemberdayaan Pendidik dan Tenaga Kependidikan Ilmu Pengetabuan Alam, (Bandung: Universitas Pendidikan Indonesia, 2013).
} 7. 120. 
Arabiyât Jurnal Pendidikan Bahasa Arab dan Kebahasaaraban, 7 (2), 2020

about the state of educational institutions that are the object of research and other supporting notes in the 2013 Curriculum.

To obtain accurate data and in accordance with the subject matter under study, the researchers used several data collection methods which complement each other, including: observation, interviews and documentation. The analysis in this study was an inductive approach, a method that departs from specific facts, from concrete events and then from these facts or events general generalizations are draw.$^{23}$

\section{Result and Discussion}

\section{Implementation of the 2013 Curriculum at Madrasah Aliyah Nurul Hikmah Haurgeulis}

Based on the results of observations, interviews and documentation at Madrasah Aliyah (MA) Nurul Hikmah Haurgeulis Indramayu for two months, from November 2019 to January 2020, the following data were obtained:

Taking into account the existing conditions, potentials and problems, and in line with the vision, mission and long-term goals of the madrasah, Madrasah Aliyah Nurul Hikmah haurgeulis establishes strategic goals to be achieved according to the eight National Education Standards, ${ }^{24}$ which are increasing Content Standards, increasing Process Standards, increasing the Outcomes Competency Standards, increasing the Standards for Educators and Education Personnel, increasing the Standards for Facilities and Infrastructure, increasing Management Standards, increasing Financing Standards and improving Education Assessment Standards. The details are:

\section{a) Improvement of Content Standards}

From the results of documentation and observation, it was found that the material for Arabic lessons in class X of Madrasah Aliyah Nurul Hikmah Haurgeulis Indramayu was in accordance with the 2013 Curriculum Content Standards, because the madrasah had used textbooks that had been provided by the Ministry of Religion. The material taught is in accordance with the established syllabus and curriculum. although the material taught is tailored to the abilities of students who have heterogeneous educational backgrounds. And judging from the existing RPP is in accordance with the 2013 Curriculum. As stated Nur Ahid et. al. that many factors and elements of the success of an education in educational institutions, one the factors and elements is the curriculum. ${ }^{25}$

b) Improvement of Process Standards

Learning activities are educational processes that provide opportunities for students to develop their potential into increasing abilities in terms of attitudes,

${ }^{23}$ Winarno Surahmad, Pengantar Penelitian Dasar dan Metode Teknik, (Bandung: Tarsito, 1982).

24 Said Hamid Hasan, "History Education in Curriculum 2013: A New Approach to Teaching History", Historia International Journal of History in Education, Vol. 14, No. 2, 2013, 164.

${ }^{25}$ Nur Ahid, et al, "Evaluation of Curriculum 2013 with Context Input Process Product Model in Schools of Kediri, Indonesia", International Journal of Psychosocial Rehabilitation, Vol. 24, No. 7, 2020. 
Arabiyât Jurnal Pendidikan Bahasa Arab dan Kebahasaaraban, 7 (2), 2020

knowledge and skills. Learning is a process, way, act of making people or living things learn. ${ }^{26}$ According to Suyono and Hariyanto, as quoted by Fadillah, the term learning comes from the basic word learning, which is an activity or a process to acquire knowledge, improve skills, improve behavior, attitudes and strengthen personality. ${ }^{27}$ Finally it can be concluded that learning is a process of interaction between educators and students as well as between students that can be done with various media and learning resources that support the learning success of students.

Three things must be considered in the standard process, namely planning, implementation and evaluation. Planning carried out by class X Arabic teacher MA Nurul Hikmah haurgeulis, Mr. Mansyur Fadhli, in between has prepared a syllabus and lesson plans that are relevant to the standard 2013 Curriculum process, the syllabus and lesson plans are designed to achieve effective learning and according to the needs of students. But with regard to learning resources, as the results of interviews with the principal and a review of the learning process in class the school has not provided textbooks according to the needs of students. Text books are only held by the teacher. Students note the material that is delivered and what the teacher writes on the blackboard.

The learning implementation did not run optimally as planned in the RPP; it still looked like the Education Unit Level Curriculum. Actually, the teacher has tried to use interactive, inspirational, fun, creative, challenging and motivating methods of students, but the students don't seem enthusiastic. This illustrates that Arabic learning at Madrasah Aliyah Nurul Hikmah Haurgeulis there are inhibiting factors in the learning process, including those who are not fluent in reading Arabic texts and the unavailability of Arabic text books for each student.

The evaluation of the learning process was carried out periodically and continuously following the learning outcomes. Among other things, by asking some students to come to the front of the class to reread and explain the material that has been delivered, questions and answers about the material that has been delivered at the previous meeting and about the subject matter that was just delivered before the lesson ends or closes and checks the student notebooks. Because, the keyword in 2013 Curriculum that has been implemented is authentic asessment. Authentic asessment is a process of assessing global awareness and the process requires that the students should demonstrate a deeper understanding of the thinking, the motivation, and the actions of various culture in order succesfully respond to the communities and the workplaces that extend well beyond their current comfort level. ${ }^{28}$ 1995), 15.

26 Pusat Pembinaan dan Pengembangan, Kamus Besar Bahasa Indonesia, (Jakarta: Balai Pustaka,

27 M. Fadlilah, Implementasi Kurikulum 2013 dalam Pembelajaran SD/MI, SMP/MTs dan SMA/MA, 15

28 Heri Retnawati, Samsul Hadi, and Ariadie Chandra Nugraha, "Vocational Hight School Teachers Difficulties in Implementing Assessment in Currialum 2013 in Yogyakarta Province of Indonesia", International Journal of Instruction, Vol. 9, No. 1, 2016. 
Arabiyât Jurnal Pendidikan Bahasa Arab dan Kebahasaaraban, 7 (2), 2020

Pedagogic competence includes the ability of teachers to conduct process assessment and learning of student and utilize the results of assessment and evaluation of student learning for the interests of student learning. ${ }^{29}$

The purpose of curriculum evaluation is to examine the overall curriculum performance in terms of various criteria. The performance indicators that are evaluated are not only limited to effectiveness, but also relevance and efficiency. One of the curriculum components that is important to evaluate is related to the learning process and learning outcomes. Sukmadinata in Poerwanti and Amri suggested three approaches in curriculum evaluation, namely: research (comparative analysis), objective approaches and multivariate mixed approaches. ${ }^{30}$ There are three main components in the scope of assessment in the 2013 Curriculum, namely the assessment of attitudes, knowledge and skills.

c) Improvement of Graduate Competency Standards

After undergoing an integral learning process, graduates of Madrasah Aliyah Nurul Hikmah Haurgeulis Indramayu are expected to have graduate abilities which include attitudes, knowledge and skills. The madrasah and teachers hope that students can achieve the expected academic targets and be able to develop their potential as members of society with the knowledge gained at madrasah. In particular the competence of graduates related to Arabic learning outcomes while studying at Madrasah Aliyah, it is hoped that students will be able to read Arabic script properly and correctly, be able to practice Arabic knowledge in everyday life according to what they have obtained in school and be able to develop it according to situations and conditions. in society and have noble character in social life as the guidance and direction of the teacher and the school when he was a student at Madrasah Aliyah Nurul Hikmah.

d) Increasing the Standards for Educators and educational staff

The standards of educators and educational staff at MA Nurul Hikmah Haurgeulis Indramayu have met the standards, namely the fulfillment of the number of educators and educational staff, the qualifications of educators and educational staff as well as the competence of educators and educational staff that are adequate and meet both feasibility and mental. But there is a little note, that the class X Arabic teacher at Madrasah Aliyah Nurul Hikmah Haurgeulis Indramayu is not an Arabic teacher educator background, but he is a graduate of the LIPIA Syari'a Faculty, although from a scientific aspect there is no doubt his competence. Although it would be nice if Arabic lessons were taught by educators with Arabic language educational backgrounds in accordance with applicable regulations in the field of education.

29 Afiful Ikhwan, "Management of Learning Assessment Using Curriculum 2013 (Case Study in Islamic Primary School (MI)Muhammadiyah 5 Wonosari Ponorogo - East Java - Indonesia)", Muaddib: Studi Kependidikan dan Keislaman, Vol. 8, No. 2, 2018.

30 Loeloek Indah Poerwanti dan Sofyan Amri, Panduan Memahami Kurikulum 2013, (Jakarta: PT. Prestasi Pustakarya, 2013), 202-213. 
Ara biyât Jurnal Pendidikan Bahasa Arab dan Kebahasaaraban, 7 (2), 2020

Because the learning process is not only related to transferring knowledge, but also to the methods and approaches used during the learning process in the classroom.

e) Improvement of Standard for Facilities and Infrastructure

From the results of observations and interviews with both the principal and the Arabic teacher, the standard of facilities and infrastructure at Madrasah Aliyah Nurul Hikmah Haurgeulis Indramayu was still inadequate, including the lack of facilities and books in the library. The books available were old, obsolete and dusty. It seems that the library was not maintained and rarely visited. In addition, and its position in the office of the teacher and principal's room, seems narrow like a warehouse limited only by bookshelves. The unavailability of textbooks for each student to be brought home as study material, the absence of a language laboratory and the lack of learning media used during learning, especially in Arabic subjects. However, the madrasa is in good condition and is well maintained and the madrasa continues to provide improvements.

f) Improvement of Management Standards

The performance of madrasah management at MA Nurul Hikmah Haurgeulis Indramayu was based on strong teamwork and partnerships with a clear vision and mission under the auspices of the Nurul Hikmah foundation and is known by all parties. Madrasah Aliyah Nurul Hikmah Haurgeulis Indramayu already has guidelines that regulate the curriculum for each unit and syllabus, educational calendar, organizational structure, division of tasks among educators, academic regulations, rules of conduct, code of ethics for relationships between fellow citizens in the madrasa environment and educational operational costs. The Nurul Hikmah Foundation houses four educational institutions in Haurgeulis and Gantar, including Madrasah Ibtidaiyah Nurul Hikmah Haurgeulis, Madrasah Tsanawiyah Nurul Hikmah Haurgeulis, Madrasah Tsanawiyah Nurul Hikmah Gantar and Madrasah Aliyah Nurul Hikmah Haurgeulis. The four educational institutions are managed and integrated respectively. in the Nurul Hikmah foundation which is headed by a chairman of the foundation. At any time, a meeting can be held to evaluate the performance of these institutions.

g) Improvement of Financing Standards

Madrasah has financial planning according to standards and seek additional financial support. Madrasah Aliyah Nurul Hikmah Haurgeulis is one of the madrasahs that receive BOS funds from the government in the management of their educational institutions. Madrasah Aliyah Nurul Hikmah Haurgeulis also manages teacher and student cooperatives to meet daily needs and learning at school.

h) Improvement of Education Assessment Standards

An Authentic assessment has to be implemented on an ongoing process and integrated in learning. Therefore, an authentic assessment is not only in accordance 
Arabiyât Jurnal Pendidikan Bahasa Arab dan Kebahasaaraban, 7 (2), 2020

with the competencies that will be achieved, but also associated to the learning model that has been applied. ${ }^{31}$

In terms of educational assessment standards, Madrasah Aliyah Nurul Hikmah Haurgeulis Indramayu has created an assessment system for students both in the academic and non-academic fields, the assessment has an impact on the teaching and learning process and the involvement of parents in their child's learning process. Academic assessments include daily assessments when students learn and have activities in school related to the material being taught, assessment of the completeness of notebooks, assessment of assignments given to students as a form of repetition of students for the material taught to them, assessment of midterm and endsemester tests. The non-academic assessment include assessment of discipline, morals and personality, accuracy in carrying out tasks, activeness in arts, sports and organizational activities.

Ramayulis stated that there are six curriculum components, namely objectives, curriculum content, media (facilities and infrastructure), strategy, learning process and evaluation. $^{32}$

The rate of economic growth and increase in national productivity is influenced by the establishment of competency standards and national education quality standards. If competency quality standards and education quality standards have been developed in accordance with the vision, mission and goals of national education, then this is set forth in the curriculum and supported by professional teachers and school principals, education is expected to produce quality human resources (HR) capable of bringing Indonesia out of the crisis. and can keep up with the acceleration of information in the era of globalization. ${ }^{33}$

\section{Factors Affecting the Implementation of 2013 Curriculum in Learning Arabic}

Based on the results of observations, interviews, and documentation, there were several factors that influence the process. The first, teacher factor. Class X Arabic teacher MA Nurul Hikmah Haurgeulis Indramayu did not meet the standards of Arabic language teachers, because he did not have a higher education background for Arabic teachers according to the subject matter he taught. His undergraduate certificate from the faculty of syari'ah at LIPIA.

The second, student factors. For some students of class X MA Nurul Hikmah Haurgeulis Indramayu, Arabic is a material that they have just encountered and they learned at Madrasah Aliyah. Because their educational background is from public schools where there are no Arabic subjects. This makes it difficult for them to follow

31 Amat Jaedun, V. Lilik Hariyanto, and Nuryadin, E.R. "An Evaluation of The Implementation of Curriculum 2013 at The Building Construction Department of Vocational High Schools in Yogyakarta ", Journal of Education, Vol. 7, No. 1, 2014.

32 Ramayulis, Imu Pendidikan Islam, (Jakarta: Kalam Mulia, 2010), 234-236.

33 E. Mulyasa, Pengembangan dan Implementasi Kurikulum 2013, Cet. Ke 6, (Bandung: PT Remaja Rosdakarya, 2015), 23. 
Arabiyât Jurnal Pendidikan Bahasa Arab dan Kebahasaaraban, 7 (2), 2020

and understand the Arabic material taught by the teacher. Coupled with the lack of textbooks that should be able to take home and study at home both before the material is taught and after learning as repetition. So it can be understood if in the learning process it appears that students are not enthusiastic about participating in learning. There are even students who have not been able to read Arabic writing well. How will you be able to follow the learning material that is taught properly if you just have difficulty reading it. But the madrasa continues to strive for guidance for students who have not been able to read Arabic writing with the Qur'an Read and Write program.

The third, facility and infrastructure factors. To support the learning process, the facilities and infrastructure at MA Nurul Hikmah Haurgeulis are inadequate. Such as the absence of a language laboratory, the lack of facilities and books in the library, the unavailability of text books for each student, the lack of learning media used such as LCD, computers and the internet. The classrooms used for the learning process were all in good condition. In each class, there are windows for air and light ventilation so that they can freely enter and make classroom conditions comfortable to use for learning.

\section{Conclusion}

After discussing and analyzing the data, this research concluded the following research results. In general, the implementation of the 2013 Curriculum in Arabic class X learning at Madrasah Aliyah Nurul Hikmah Haurgeulis Indramayu is in accordance with the provisions and rules of the 2013 Curriculum, namely using a scientific approach consisting of observing, asking, experimenting, association and communication and has reached three domains in the learning process, namely attitudes, knowledge and skills. Whereas in the assessment, the teacher has used authentic assessment, which is a significant measurement of students in the three areas being assessed, namely attitude assessment, knowledge assessment and skills assessment. Although there are several things that cause the implementation of the 2013 Curriculum at Madrasah Nurul Hikmah Haurgeulis to be not optimal, especially in learning Arabic, because there are several factors that affect the implementation process of implementing the 2013 Curriculum. Factors that influence the application of the 2013 curriculum in Arabic learning at the madrasah among them the teacher factors, the student factors and the facilities and infrastructure factors as previously explained.

For Madrasah Aliyah Nurul Hikmah Haurgeulis, it is hoped that in the future it will continue to improve everything that is still lacking, including the linearity of education for Arabic teachers who teach Arabic, which should be adjusted to the subjects they are teaching. Likewise with the supporting and supporting facilities and infrastructure in the implementation of the 2013 Curriculum, at least a handbook for each student so that they can be brought home and studied at home before and after the material is delivered in class, especially for beginner students who have never previously studied Arabic. and of course learning becomes more efficient. It is hoped 
Arabiyât Jurnal Pendidikan Bahasa Arab dan Kebahasaaraban, 7 (2), 2020

that by correcting these deficiencies, better results will be achieved in learning Arabic based on the 2013 Curriculum at Madrasah Aliyah Nurul Hikmah Haurgeulis. []

\section{REFERENCES}

Abdurrahman, Dudung. Pengantar Metode Penelitian. Yogyakarta: Kurnia Kalam Semesta, 2003.

Ahid, Nur. et. al. "Evaluation of Curriculum 2013 with Context Input Process Product Model in Shcools of Kediri, Indonesia", International Journal of Psychosocial Rehabilitation, Vol. 24, No. 7, 2020.

Albantani, Azkia Muharom. "Implementasi Kurikulum 2013 pada Pembelajaran Bahasa Arab di Madrasah Ibtidaiyah", Arabiyat: Jurnal Pendidikan Bahasa Arab dan Kebahasaaraban, Vol. 2 No. 2, 2015.

Arikunto, Suharsimi. Prosedur Penelitian Suatu Pendekatan Praktek: Edisi Revisi V. Jakarta: Renika Cipta, 2002.

Asifudin, Ahmad Janan. Mengukir Pilar-Pilar Pendidikan Islam, (Tinjauan Filosofis). Yogyakarta: Suka Press, 2010.

Effendy, A. Fuad. Metodologi dan Strategi Alternatif (Pembelajaran Bahasa Arab). Malang: Misykat. 2005.

Fadlilah, M. Implementasi Kurikulum 2013 dalam Pembelajaran SD/MI, SMP/MTs dan SMA/MA. Yogyakarta: Ar-Ruzz Media, 2014.

Faisol, Sanapiah. Format-format Penelitian Sosial. Jakarta: Raja Grafindo Persada, 2007.

Fauzan., and Anis Fuadah Zuhri. "Analysing The Essence of Fiqh Subjects in Curriculum 2013", Abkam, Vol. 17, No. 1, 2017.

al-Ghulayain, Musthafa. Jami' Ad-Durus Al-'Arabiyah. Al-Iskandariyah: Dar Al-'Aqidah, 2014.

Imam Gunawan. "Indonesian Curriculum 2013: Instructional Management, Obstacles Faced by Teachers in Implementation and the Way Forward", ICET, Atlantis Press, Advences in Social Science, Education and Humanities Research, Vol. 128, 2017.

Hasan, Said Hamid. "History Education in Curriculum 2013: a New Approach to Teaching History", Historia: International Journal of History in Education, Vol. 14, No. 2, 2013.

Hasyim, M. "Andragogi dalam Pembelajaran Bahasa Arab”, Arabiyat: Jurnal Pendidikan Bahasa Arab dan Kebahasaaraban, Vol. 2, No. 1, 2015.

Ikhwan, Afiful. "Management Of Learning Assessment Using Curriculum 2013 (Case Study In Islamic Primary School (MI) Muhammadiyah 5 Wonosari Ponorogo - East Java Indonesia)", Muaddib: Studi Kependidikan dan Keislaman, Vol. 8, No. 2, 2018.

Jaedun, Amat., V. Lilik Hariyanto, and E.R. Nuryadin. "An Evaluation of The Implementation of Curriculum 2013 at The Building Construction Department of Vocational High Schools in Yogyakarta", Journal of Education, Vol. 7, No. 1, 2014. 
Arabiyât Jurnal Pendidikan Bahasa Arab dan Kebahasaaraban, 7 (2), 2020

Kusumaningsih, Dewi. "Indonesian Text Role as Draft Science in Curriculum 2013: Assessment Introduction Text Structure Strategies in an Indonesian Book", Asian Journal of Social Sciences \& Humanities, Vol. 2, No. 4, 2013.

Moleong, Lexy J. Metodologi Penelitian Kualitatif. Bandung: Remaja Rosdakarya, 2002.

Mulyasa, E. Pengembangan dan Implementasi Kurikulum 2013. Bandung: PT Remaja Rosdakarya, Cet. Ke 6, 2015.

Nur, Maulidia Rachmawati., and Ahmad Madkur. "Teachers Voices on The 2013 Curriculum for English Instructional Activities", IJEE, Vol. 1, No. 2, 2014.

Poerwanti, Loeloek Indah., dan Amri, Sofyan. Panduan Memahami Kurikulum 2013. Jakarta: PT. Prestasi Pustakarya, 2013.

Prasetianto, Mushoffan. "CLIL: Suggested English Materials for Curriculum 2013", Language Circle, Journal of Language and Literature, Vol. 8, No. 2, 2014.

Prastowo, Andi, "Transformasi Kurikulum Pendidikan Dasar dan Menengah di Indonesia (Kurikulum Tingkat Satuan Pendidikan Menuju Kurikulum 2013 hingga Kurikulum Ganda)", Jurnal Ilmiah PGMI, Vol. 4, No. 2, 2018.

Pusat Pembinaan dan Pengembangan. Kamus Besar Bahasa Indonesia. Jakarta: Balai Pustaka, 1995.

Ramayulis. Ilmu Pendidikan Islam. Jakarta: Kalam Mulia, 2010.

Retnawati, Heri., Samsul Hadi, and Ariadie Chandra Nugraha. "Vocational Hight School Teachers Difficulties in Implementing Assessment in Curriculum 2013 in Yogyakarta Province of Indonesia", International Journal of Instruction, Vol. 9, No. 1, 2016.

Sanjaya, Wina. Kurikulum dan Pembelajaran. Jakarta: Kencana Prenada Media Group, 2009.

Sulfemi, Wahyu Bagja. Manajemen Kurikulum di Sekolah: Modul Pembelajaran Program Studi Administrasi Pendidikan STKIP Muhammadiyah Bogor. Bogor: Visi Nusantara Maju, 2018.

Surahmad, Winarno. Pengantar Penelitian Dasar dan Metode Teknik. Bandung: Tarsito, 1982.

Taufiq, Wildan. Metode Penelitian Bahasa Arab. Bandung: PT Refika Aditama, 2018.

Virgiana, Angga. Strategi Pengembangan Kompetensi Widyaiswara dalam Pengelolaan Pembelajaran di Lembaga Pusat Pengembangan dan Pemberdayaan Pendidik dan Tenaga Kependidikan Ilmu Pengetahuan Alam. Bandung: Universitas Pendidikan Indonesia, 2013.

Zulhanan. Paradigma Baru Pembelajaran Bahasa Arab (Kajian Teoritis dan Praktis). Bandar Lampung: An-Nur Press, 2004. 